\title{
KATEGORIA MOŻLIWOŚCI W MYŚLI I PISARSTWIE SØRENA KIERKEGAARDA
}

EDWARD KASPERSKI

\section{RODZAJE MOŻLIWOŚCI}

Kategorię możliwości (duń. mulighed) w myśli i pismach Sørena Kierkegaarda trudno przecenić. Stanowi ona w jego wykładni właściwość różnych sfer rzeczywistości, zarówno przyrodzonej, jak i nadprzyrodzonej, występuje jako znamię i składnik ludzkiej egzystencji oraz pojawia się w roli pojęciowego instrumentu stosowanego w odmiennych, niejednokrotnie odległych od siebie dziedzinach. Jej wielorakie sposoby uobecniania się oraz rozległe zastosowania sprawiają jednakże, iż znamionuje ją - jeśli śledzimy jej ekspresje i kształty w poszczególnych wypowiedziach, tekstach i dyskursach duńskiego myśliciela - rzucająca się w oczy polisemia (w niektórych sytuacjach można by mówić wręcz o homonimii) oraz rozległa kontekstualizacja, różnicująca jej poszczególne postacie, znaczenia i zastosowania. Dotyczy to także oddziaływania kategorii możliwości bądź też jego braku oraz powodowanych przez nią skutków. Ucieleśniają one określone - pozytywne bądź negatywne - wartości, motywujące z kolei stosowne oceny, wnioski i diagnozy formułowane wprost przez samego Kierkegaarda lub pośrednio przez jego pseudonimy. Również i one, wspomniane oceny, wnioski i diagnozy, podlegają, warto zaznaczyć, zróżnicowaniu, zniuansowaniu i swoistej relatywizacji (kontekstualizacji).

By posłużyć się przykładem, dla estety uwięzionego beznadziejnie w immanencji rzeczywistości i pogrążonego w nudzie perspektywa możliwości a więc wyjścia poza ów krąg wewnętrznego bezruchu oraz wejścia w sferę 
wyboru i rozwoju duchowego - wydaje się czymś pożądanym i zbawiennym¹ ${ }^{1}$ Tymczasem odwrotnie, losem tegoż estety w sytuacji, gdy zdał się wyłącznie na kontemplowanie barwnych, kuszących, zjawiających się kalejdoskopowo możliwości, bez konfrontacji ich z rzeczywistością i przejścia do wyboru i realizacji którejś z nich, staje się rozpacz, beznadzieja, ruch w błędnym kole. W planie egzystencjalnym, źródłem przygnębienia, melancholii i rozpaczy okazuje się zatem zarówno dokuczliwy deficyt możliwości, jak i - na przeciwnym biegunie - ich nadmiar, paraliżujący akt wyboru, zajęcie zdecydowanej postawy i działanie. W dialektycznym myśleniu Kierkegaarda możliwość - w sytuacji egzystencjalnego deficytu - oznaczać może bowiem rzecz gorąco pożądaną, ważniejszą niż wszystko inne, a z kolei w sytuacji nadmiaru i estetycznego delektowania się rozmaitymi możliwościami egzystencjalnymi - rzecz szkodliwą i duchowo zabójczą.

Wszystkie te powyższe właściwości wespół z wieloma enigmatycznymi sformułowaniami ${ }^{2}$ utrudniają czy też wprost uniemożliwiają sprowadzenie omawianej kategorii do w pełni przejrzystej, jednoznacznej, dysponującej wyraźnymi granicami, inwariantnej postaci. Konieczna staje się zatem wstępna, robocza typologia jej rozmaitych odmian i rozlicznych zastosowań, tym bardziej że kategoria ta pojawia się w zróżnicowanych kompozycyjnie, stylistycznie, gatunkowo i funkcjonalnie pismach Kierkegaarda, które z natury rzeczy i same w sobie rzutują na sposób jej ujęcia i na języ-

1 „Moja dusza utraciła możliwość - wyznawał anonimowy autor i bohater Diapsalmatów otwierających pierwszy tom Albo-albo - Jeśli więc mógłbym sobie czegoś życzyć, to nie życzyłbym sobie bogactwa lub władzy, lecz namiętnego pragnienia możliwości [Mulighedens Lidenskab], tego oka, które wszędzie pozostaje wiecznie młode, wiecznie pałające - widzi możliwość. Rozkosz rozczarowuje, możliwość - nie”. S. Kierkegaard, Samlede Vorker, t. 2, Kopenhaga 1962, s. 42 (dalsze cytaty ze zbioru dzieł wybranych Kierkegaarda oznaczam jako SV i lokalizuję bezpośrednio w tekście, podając numer tomu oraz stron/y); wszystkie tłumaczenia z języka duńskiego pochodzą od autora artykułu. Zob. także: S. Hüsch, Langeweile bei Heidegger und Kierkegaard. Zum Verhältnis philosophischer und literarischer Darstellung, Tübingen 2014, s. 151-152.

2 Przykładem może być definicja lęku, w której możliwość pojawia się jako definiens: „lęk jest rzeczywistością wolności jako możliwość dla możliwości („Angest er Frihedens Virkelighed som Mulighed for Muligheden"), S. Kierkegaard, Begrebet Angest, Cap. I, $₫ 5$, http://sks.dk/BA/txt.xml (SV, 6, s. 136). 
kowe zabarwienie. Rozważania lub uwagi na temat możliwości pojawiają się bowiem - z jednej strony - w poszczególnych, odmiennie wystylizowanych utworach pseudonimowych (Albo-albo, Zamykajace nienaukowe postscriptum, Pojęcie lęku, Choroba na śmierć i inne), jedynie pośrednio wskazujących na stanowisko i poglądy samego Kierkegaarda, ponieważ ujawnia się on w tych pismach w roli „autora pseudonimowych autorów” i neutralnego w założeniu „sekretarza” wypowiedzi przypisanych fikcyjnym narratorom i/lub postaciom pseudonimowym. Z drugiej strony, Kierkegaard-autor wypowiadał się także bezpośrednio w licznych pismach sygnowanych własnym nazwiskiem, w brulionach, szkicach i notatkach, by wymienić tu jedynie tytułem przykładu prowadzony przez lata dziennik (Journalen) ${ }^{3}$.

Przejdźmy zatem do wyodrębnienia głównych obszarów występowania kategorii możliwości i jej rozmaitych zastosowań oraz sensów.

\section{ZNACZENIE ONTOLOGICZNE}

Istnienie pozytywnej i systematycznej refleksji ontologicznej u Kierkegaarda jest sporne, a w każdym razie trudne od wytropienia i zaprezentowania. John W. Elrod, który wiele lat temu zajmował się tym zagadnieniem, sceptycznie patrzył na konstrukcję takiej ontologii u myślicieli egzystencjalnych - a więc także u Kierkegaarda. Według Elroda napotyka ona trudne do pokonania przeszkody, ponieważ jej twórcy negują myślenie esencjalne oraz w kontraście do niego przyjmują, iż egzystująca jednostka jest w całym swoim życiu nieprzerwanie i nieodwołalnie zanurzona w procesie stawania się i z tego powodu „nie może ona przekroczyć egzystencji i ująć jej jako całości"'.

Z drugiej jednak strony, niektóre uwagi i wywody zawarte w pismach Kierkegaarda, także te negatywne, wskazują co najmniej na rudymenty i przebłyski dyskursu ontologicznego. Taki charakter miały na przykład Okruchy filozoficzne Johannesa Climacusa, (czyli samego Kierkegaarda

3 Dzienniki Kierkegaarda (Journalen) zostały w ostatnich latach opublikowane w układzie chronologicznym i w elektronicznej wersji duńskiej jako ogniwo cyklu Søren Kierkegaards Skrifter elektronisk version 1.8.1 ved Karsten Kynde, vol. 17-26. Istnieje także wielotomowy angielski przekład dzienników.

${ }^{4}$ J.W. Elrod, Being and Existence in Kierkegaard's Pseudonymous Works, Princeton 2015 [1975], s. 28. 
ukrywającego się pod tym pseudonimem), poświęcone problematyce ruchu i zmiany, konfrontujące zmianę rzeczy już istniejącej ze zmianą, która towarzyszy powstaniu rzeczy nowej. „Otóż taki byt [veren], który wszakże jest nie-bytem [ikke-voren] - konkludował Climacus-Kierkegaard - jest możliwością; zaś byt, który w pełni jest bytem, jest bytem rzeczywistym, czyli po prostu rzeczywistością; toteż zmiana towarzysząca powstaniu czegoś [tilblivelsens forandring] jest przejściem możliwości w rzeczywistość” (SV, 6, s. 68). Podobnie należałoby potraktować zawartą w rozprawie Choroba na śmierć definicję „rzeczywistości”, która głosi, że stanowi ona „jedność możliwości i konieczności [virkelighed er eenhed af mulighed og nødvendighed]" (SV, 15, s. 94). W obu podanych sytuacjach kategorie bytu, konieczności i możliwości przybierają sens ontologiczny i uczestniczą w dyskursie ontologicznym, traktowanym zresztą w sposób epizodyczny - jako wsparcie argumentacji dotyczącej innych zagadnień.

Trudno tu oprzeć się wrażeniu, iż Kierkegaard - przeciwnik zbyt dla niego abstrakcyjnej oraz pustej w zasadzie metafizyki i ontologii praktykowanych przez współczesny mu idealizm obiektywny oraz filozofię spekulatywną epoki - wprowadza omawiane kategorie sporadycznie, na zasadzie polemicznego uwikłania i uzależnienia, niejako tylnymi drzwiami. Uznaje bowiem możliwość, podobnie jak konieczność, za komponent i właściwość rzeczywistości jako takiej, rzeczywistości w ogóle. Już przecież samo pojęcie „rzeczywistości w ogóle” wskazuje na ślady (czy pozostałości) myślenia ontologicznego i metafizycznego. W kontekście przytoczonej definicji jest zatem zasadne mówienie o ontologicznym rozumieniu i zastosowaniu kategorii możliwości - jako czynnika współkonstytuującego rzeczywistość.

\section{MOŻLIWOŚĆ JAKO CZYNNIK STAWANIA SIĘ EGZYSTENCJI I BYTU}

Przeciwstawiając się abstrakcyjnemu i systemowemu myśleniu kojarzonemu z Heglem i heglistami, Kierkegaard wskazywał, że myślenie tego rodzaju dokonuje się sub specie aeterni i w konsekwencji - operując pojęciami „czystego myślenia” i „czystego bytu” - unieruchamia, odsuwa na boczny tor i deformuje takie realne zjawiska, jak ruch, zmiana, rozwój, sprzeczność, przejście, skok czy stawanie się, które w świetle wywodów Duńczyka objaśniają na równi ludzką egzystencję i rzeczywistość i które bez uwzględnienia kategorii możliwości (jako odpowiednika potencjalności) byłyby niemożliwe i nie do pomyślenia czy objaśnienia. „Kierkegaard, podobnie 
jak Arystoteles - pisała Clare Carlisle, autorka książki o pojęciu stawania się u duńskiego myśliciela - argumentuje, iż idee [platońskie - przyp. E.K.] same w sobie nie mogą spowodować ruchu i wyjaśnić rzeczywistości; obaj myśliciele przeciwstawiają się zatem idealizmowi, poszukując źródła ruchu wśród istniejących rzeczy"5. Arystoteles zwracał uwagę na istnienie takiego ruchu (kinesis) w fizycznej naturze, Kierkegaard, przeciwnie, w egzystującym człowieku, w jego subiektywności ${ }^{6}$. Kierkegaard-Johannes Climacus stwierdzał wprost: „Egzystencja nie daje się w ogóle pomyśleć bez ruchu, a ruch nie daje się pomyśleć sub specie aeterni” (SV, 10, s. 15).

W ujęciu Kierkegaarda możliwość stanowiła wewnętrzną właściwość wszystkich wspomnianych zjawisk: ruchu, przejścia rzeczy z jednego stanu w drugi, przejścia z niebytu w byt, zmiany, stawania się itd. Działała w sferze natury, historii, jednostkowej egzystencji. Pojawienie się możliwości zaprzeczało zatem poglądowi o istnieniu „obiektywnej”, znieruchomiałej i statycznej rzeczywistości zarówno pozapodmiotowej, jak egzystencjalnej i subiektywnej. Kategoria możliwości stanowiła ponadto oręż w zwalczaniu koncepcji deterministycznych lub fatalistycznych, traktujących dzianie się i stawanie mechanicznie - jako funkcjonowanie w założonej z góry postaci i sterowane przez samą konieczność. O ile stawanie się natury czy historii nie było, jak można sądzić, wynalazkiem Kierkegaarda, o tyle uznanie

${ }^{5}$ Niektóre konteksty filozoficzne kategorii stawania się wydobywa Clare Carlisle w pracy: Kierkegaard's Philosophy of Becoming: Movements and Positions, New York 2005, rozdział I: Metaphysics of Motion, s. 9-22; cytowany fragment: ibidem, s. 12.

6 Zob. ibidem, s. 18: „Kierkegaard chce przenieść Arystotelesowskie pojęcie realnego przejścia do dziedziny tego, co wewnętrzne [into the realm of inwardness], do serca potencjalności, aby zabezpieczyć wolność tego przejścia”. W interpretacji tej Carlisle idzie, moim zdaniem, za daleko. Otóż, zawężając drastycznie pojęcia ruchu i przejścia do sfery subiektywnej, negując w ogóle stawanie się bytu, Kierkegaard podważałby własne wyeksponowane stanowisko egzystencjalne dotyczące stawania się jednostki i w ogóle człowieka. Dezawuowałby również pośrednio własne koncepcje działania i historii powszechnej (Verdenhistorien). Podejmując wnikliwą interpretację ruchu i akcentując jego znaczenie egzystencjalne, Kierkegaard odnosił się jednakże krytycznie do Heraklitejskiej koncepcji panta rei oraz dopuszczał występowanie w stawaniu się elementów zatrzymania, spoczynku, bezruchu i ciągłości. Zob. SV, 10, s. 18-19. 
pojedynczej egzystencji za będącą w ruchu i stającą się oraz zanurzenie jej w stawaniu się było jednym z jego kluczowych rozwiązań. Uzasadniały je, $\mathrm{z}$ jednej strony, omawiana kategoria możliwości, $\mathrm{z}$ drugiej - powiązanie tej ostatniej z wolnością (SV, 6, s. 71).

\section{EPISTEMOLOGICZNE ZNACZENIE KATEGORII MOŻLIWOŚCI}

Kategorii możliwości Kierkegaard nadał również wyraziste znaczenie epistemologiczne. Podważał za jej pośrednictwem, z jednej strony, twierdzenie Hegla o jedności myślenia i bytu, z drugiej - uzasadniał nią istnienie nieprzekraczalnej różnicy i granicy dzielącej obiektywny świat pozapodmiotowych faktów, relacji i wydarzeń oraz myślenie, a dokładniej, pojęciowe poznanie dostarczające wiedzy o tym świecie. Myślenie, poznanie i wiedza nie były jednakże w stanie dotrzeć do konkretnej, zewnętrznej i niezależnej od poznającego podmiotu rzeczywistości empirycznej, idealnej (spekulatywnej) lub historycznej, oraz w sposób adekwatny - a więc jednoznaczny i niezawodny - jej zgłębić, odzwierciedlić i zakomunikować o niej. Nie potrafiły uzyskać statusu prawdy absolutnej, a w konsekwencji uzasadnić poglądu o „jedności” poznającej myśli oraz poznawanego przez nią świata.

Zasadniczy argument Kierkegaarda w tej kwestii głosił, iż rzeczywistość oraz myślenie reprezentują dwie jakościowo różne sfery bytu i że nie można zniwelować ich odrębności i specyfiki, zatrzeć dzielących je jakościowych różnic, a następnie dowolnie zastąpić jedno drugim. Rzeczywistość zewnętrzna uosabia bowiem dla podmiotu poznającego materialną i zmysłową konkretność, myślenie - refleksję, pierwiastki idealne i ogólność. Toteż rzeczywistość jako taka nie wchodzi bezpośrednio w skład poznania i wiedzy - nie tworzy mianowicie ich wewnętrznej, integralnej cząstki w swej przedmiotowej, uprzedniej i zastanej, fizycznej, zmysłowej lub nawet idealnej postaci. Występuje ona natomiast w poznaniu zawsze i wszędzie jako „rzeczywistość pomyślana [tonkte virkelighed]” (SV, 10, s. 26). Znaczy to, że bez jej pomyślenia nie ma i nie może być dostępu do niej. Dostęp poznawczy wymaga z kolei transformacji i przekładu przedmiotowej rzeczywistości na jakościowo i funkcjonalnie różne od niej kategorie myślowe, pojęciowe i językowe, zawierające pierwiastki idealizacji oraz ogólności. Tymczasem zdaniem Kierkegaarda, reprezentowanego w tym wypadku przez Johannesa Climacusa, taka „pomyślana rzeczywistość” jest niczym innym, jak właśnie „możliwością”, iż rzeczy mają się tak, a nie inaczej. 
Każde poznanie rzeczywistości zewnętrznej wobec podmiotu poznającego uzyskiwało w rezultacie jedynie status wiedzy możliwej, odrębnej i różnej od poznawanego przedmiotu, skierowanej wprawdzie ku niemu, ale w żaden sposób nie identycznej z nim.

Utożsamiając poznanie rzeczywistości z jej pomyśleniem, a pomyślenie z możliwością, że rzeczy istnieją w taki czy inny sposób lub mają takie, a nie inne właściwości, Kierkegaard znacząco relatywizował (i detronizował!) świeckie, naukowe poznanie i jednocześnie otwierał wrota dla swoiście przez siebie pojmowanej wiary, radykalnie poróżnionej z wiedzą, poznaniem i rozumem, utożsamionej z aktem woli i namiętnością. Podważał jednocześnie również ideę poznania absolutnego i prawdy absolutnej, a zwłaszcza przekonanie, iż są one osiągalne w poznaniu naukowym i filozoficznym. Każda wiedza: empiryczna - przyrodnicza, historyczna lub socjologiczna; rozumowa (logiczna) lub filozoficzna (spekulatywna) - uosabiała w zarysowanej przez niego perspektywie jedynie modus wiedzy możliwej, ale nie ostatecznej, wiecznej czy po prostu niepodważalnej. Mogła więc z czasem ulec rewizji i znaczącej modyfikacji. Tryby wiedzy i wiary mijały się w sposób ostateczny i nieodwołalny.

\section{EGZYSTENCJALNO-ANTROPOLOGICZNE ZNACZENIE I ZASTOSOWANIE MOŻLIWOŚCI}

Kategoria możliwości miała u Kierkegaarda również szerokie zastosowanie egzystencjalno-antropologiczne. Stanowiła między innymi aktywny komponent ludzkiej, osobowej jaźni. W Chorobie na śmierć filozof, ukryty pod pseudonimem Anti-Climacus, stwierdzał:

Aby podlegać stawaniu się (a jaźń powinna oczywiście stawać się sama w sposób swobodny), równie istotne są w tym względzie możliwość i konieczność. Podobnie jak przynależą do jaźni nieskończoność i skończoność (gr. apeiron-peras), analogicznie przynależą do niej także możliwość i konieczność. Jaźń, która nie dysponuje żadną możliwością, pogrąża się w rozpaczy i podobnie zresztą dzieje się z jaźnią, która nie doświadcza żadnej konieczności (SV, 15, s. 92).

Uwewnętrznienie kategorii możliwości rozstrzygało więc o kondycji normalnej, „pełnej” jednostki, podczas gdy jej brak rodził efekt - jak obrazowo przedstawiał rzecz Anti-Climacus - wegetowania w zamkniętym, 
pozbawionym perspektywy świecie przygnębiających trywialności, a w granicznych sytuacjach - upodabniał się fizjologicznie do braku tchu i duszenia się.

W szerszym rozumieniu kategoria możliwości odnosiła się całościowo do jednostkowej, subiektywnej egzystencji. W grę nie wchodziło jednakże ujęcie tejże egzystencji w porządku myśli i pojęć, w sposób intersubiektywny, zobiektywizowany lub esencjalny. Celem nie było jej poznawcze wymodelowanie, zdefiniowanie i skatalogowanie na podstawie badań, analiz czy obserwacji. Było nim natomiast ujęcie jej niejako od wewnątrz - jako egzystującej podmiotowości zagłębiającej się w siebie i stanowiącej o sobie samej, poza obrębem zewnętrznych, osaczających ją uwarunkowań i determinacji. W tym jednostkowym, subiektywnym i wewnętrznym wymiarze stanowiła ona o własnym, przeżywanym istnieniu, stawaniu się, byciu, nieporównywalnym z kimkolwiek innym, niewymiennym na cudze doświadczenie by wspomnieć w tym miejscu o zawsze tlącej się w podświadomości myśli o możliwości własnej śmierci, niemożliwej przecież do zastąpienia czyjąś inną podświadomością śmierci lub samą śmiercią, będącą zarazem w planie subiektywnej egzystencji wymownym, sugestywnym przykładem prymatu możliwości nad rzeczywistością.

W ujęciu tego typu egzystencja rysowała się zatem nie jako uprzedmiotowiona rzeczywistość - nie różniłaby się ona wówczas od dowolnego innego przedmiotu poznania - lecz właśnie jako możliwość możliwości realizujących się $\mathrm{w}$ powszednim trybie $\mathrm{w}$ porządku przejścia od tego, co możliwe, do tego, co realne. W języku Kierkegaarda (również w tekstach opatrzonych jego pseudonimami) oznaczało to możliwy ruch egzystencjalny ab posse ad esse. Owa „możliwość możliwości” wyrażała się - jak to precyzował Johannes Climacus w Okruchach filozoficznych oraz w Nienaukowym zamykającym postscriptum - w wolnym przejściu od braku rzeczywistości w ogóle do jej zaistnienia, nie zaś w konkretnych przejściach od jednego stanu do innego, słowem, od sprecyzowanego stanu możliwego do realnego ${ }^{7}$. Można by rzec, iż w subiektywnej egzystencji jako takiej możliwość poprzedzała generalnie każdą rzeczywistość, podczas gdy w realnym,

7 Przejścia ab posse ad esse i ab essse ad posse - od możliwości do bycia i odwrotnie - charakteryzował Climacus (SV, 10, s. 27). 
psychologicznym i społecznym istnieniu jednostki rzeczywistość, odwrotnie, poprzedzała możliwość.

Możliwość w subiektywnym planie egzystencjalnym - jako ogólny warunek zawieszenia albo zaktualizowania pewnej możliwości cząstkowej - nie dotyczyła zatem realizacji jakiegoś planu lub marzenia. Nie wyrażała się w wymiernych decyzjach, działaniu i efektach, dajmy na to - w zamiarze zdobycia nieopanowanej dotąd, ale majaczącej na horyzoncie umiejętności lub w nabywaniu dóbr pozostających dotychczas jedynie w planie pragnienia i nadziei posiadania. Jej istotą było według Kierkegaarda to, że nie dotyczyła ona konkretnej rzeczy - nie była mianowicie ani odczuciem jej braku, ani perspektywą usunięcia deficytu. Odnosiła się natomiast do egzystencji jako całości. Stosowała się, innymi słowy, do kwestii być albo nie być, a więc do samej możliwości pojawienia się lub zawieszenia konkretnej możliwości.

Toteż następstwem tego braku wykrystalizowania okazywał się lęk przed nicością ${ }^{8}$. Ten niezwykły lęk, który powstawał z pojawienia się „możliwości dla możliwości”, Kierkegaard kojarzył z ukonstytuowaniem się duchowości, wolnością oraz formowaniem się osobniczej jaźni. Właściwości tego rodzaju radykalnie oddzielały (różniły) człowieka od świata zwierząt. Torowały one również drogę przejściu ze stanu nieświadomości i niewinności, gdzie wolność występowała jedynie w zalążku, w formie przeczucia, do świadomości grzechu i poczucia winy, a więc do wyboru i zajęcia postawy religijnej, a także do wiary, w której zawierała się możliwość zbawienia, transcendentna w stosunku do rzeczywistości i podporządkowująca ją sobie.

Warto podkreślić, że w tym swoistym, egzystencjalnym rozumieniu możliwości cała rzeczywistość ulegała wzięciu w nawias i zawieszeniu. Wszystko w człowieku i wokół niego stawało się jednakowo możliwe lub

8 Kierkegaard odróżniał lęk (angest) od strachu (frygt). Strach odnosił się bowiem według niego do czegoś konkretnego, lęk natomiast wyrastał ze wspomnianej „rzeczywistości wolności jako możliwości dla możliwości”. Charakteryzował on jedynie człowieka - jego duchowość (aand) - i nie występował w ogóle u zwierząt, duchowości pozbawionych (SV, 6, s. 136).

9 W tym duchu duński badacz Kierkegaarda Arne Grøn interpretował jego rozprawę Pojęcie lęku. Zob. A. Grøn, Begrebet angst hos Søren Kierkegaard, Kopenhaga 1994; oraz: idem, The Concept of Anxiety in Søren Kierkegaard, trans. J.B.L. Knox, Macon 2008. 
niemożliwe - łącznie z samym realnym egzystowaniem - zanim w ogóle mogła pojawić się myśl o jakimkolwiek urzeczywistnieniu. Takie zawieszenie i zanegowanie wszelkiej rzeczywistości budziło, zdaniem Kierkegaarda, do życia podmiotowość jako „czystą możliwość” i kierowało ją ku sobie samej. Ustanawiało za sprawą wolności - podmiotowego atrybutu ducha wspomnianą egzystencjalną „możliwość dla możliwości”.

Ten prymat możliwości nad rzeczywistością stanowił warunek i rdzeń subiektywnej egzystencji. Możliwość oznaczała tu także pochodnie prymat nad rozumem, rozsądkiem, doświadczeniem, warunkami, realizacją itp. Najważniejsze było jednak to, że dopuszczała przekonanie, iż możliwe jest także to, co w kategoriach rzeczywistości było absolutnie niemożliwe, a więc na przykład to, że konkretny, pojedynczy, historyczny człowiek, czyli Jezus Chrystus, był bogiem.

\section{MOŻLIWOŚĆ W SFERZE ETYKI}

Kategoria możliwości charakteryzowała również w pewnym istotnym względzie etyczną kondycję podmiotu egzystującego, rozpiętego między wewnętrzną świadomością istnienia etycznej możliwości czynienia dobra oraz realnym działaniem, polegającym na urzeczywistnieniu tej możliwości. Przejście typu ab posse ad esse było możliwe jedynie w nacechowanym etycznie, intencjonalnym działaniu pojedynczego podmiotu, przenoszącego swój wewnętrzny, nieodparty imperatyw etyczny (istniejący początkowo jako możliwość) w konkretne działanie i praktyczną realizację. „Etyka zakłada bowiem - pisał Kierkegaard w niepublikowanych za życia notatkach - że każdy człowiek wie, na czym etyka polega, a dlaczego? Ponieważ etyka domaga się, aby każdy człowiek w każdym momencie [życia - przyp. E.K.] ją realizował, a zatem musi on ją znać. Etyka nie zaczyna zatem od niewiedzy, którą należy zastąpić wiedzą, lecz zaczyna od wiedzy i domaga się realizacji” 10 . Realizacja ta wyrażała się nie tyle w „zewnętrznym działaniu”, ile - jak pisał Climacus w Nienaukowym kończacym postscriptum - „w rzeczywistości wewnętrznej, w której jednostka znosi możliwość i identyfikuje się z tym, co pomyślane, aby w nim egzystować. I to właśnie jest działanie

10 S. Kierkegaard, Den ethiske og den ethisk-religieuse Meddelelses Dialektik, Papirer VIII 2B 81.10, http://sks.dk/p364/txt.xml. 
[etyczne - przyp. E.K.]" (SV, 10, s. 42). Rzeczywista realizacja wyrażała się zatem w ruchu, przejściu i skoku do rzeczywistości innej niż pomyślana.

Ale kategoria możliwości miała także inne zastosowanie etyczne niż tylko wewnętrzne. Otóż próba zrozumienia i oceny cudzej postawy etycznej - charakteryzującej dowolne inne podmioty niż my sami - oznaczała, iż rzeczywistość etyczna tego cudzego podmiotu stawała się dla nas wyłącznie „możliwością”. Prawdziwe, pełne i pewne poznanie tej cudzej rzeczywistości etycznej z zewnątrz było bowiem nieosiągalne, niedostępne dla zewnętrznego spojrzenia. Napotykało ono na niemożliwą do prawdziwego, poznawczego przeniknięcia intymną naturę subiektywności, zachowującej tajemnice wnętrza jedynie dla siebie samej.

Dokonywało się tutaj konieczne przejście typu ab esse (od autentycznej, wewnętrznej rzeczywistości etycznej danego podmiotu) ad posse (ku percepcji i obróbce myślowej innego, usytuowanego na zewnątrz obserwatora). Otóż ta swoista rzeczywistość etyczna przynależna pierwszemu podmiotowi rysowała się w owym zewnętrznym akcie poznania i oceny wyłącznie jako jedna $\mathrm{z}$ egzystencjalnych możliwości, ale nie jako bezwzględna prawda, uzasadniająca ferowanie, dajmy na to, potępiających ocen moralnych. Ujęcie z zewnątrz wykluczało niezawodne ustalenie tego, czy dana osoba mówi prawdę, czy przeciwnie - kłamie; czy jej wypowiedź jest asercją, ironią czy naganną hipokryzją. Kierkegaard wyciągał stąd wniosek, że kategoryczna moralna ocena innego człowieka jest po prostu niemożliwa, gdyż sądząc innych, sądzimy w istocie rzeczy samych siebie.

Konsekwencje powyższych założeń i ustaleń były wielokierunkowe i dalekosiężne. Podważały one na przykład rozpowszechniony pogląd, że literatura, psychologia, filozofia lub teologia docierają do głębi ludzkiej rzeczywistości duchowej i moralnej - do rdzenia jednostkowej egzystencji - że precyzyjnie są w stanie ją rozpoznać i przekazać o niej niepodważalną wiedzę i prawdę. Tymczasem zdaniem Kierkegaarda pisząca jednostka - poeta, pisarz, badacz, filozof, teolog - docierała w istocie rzeczy w tworzonym przez siebie obrazie innego człowieka tylko do własnej, prymarnej rzeczywistości etycznej, podczas gdy wewnętrzna rzeczywistość drugiego człowieka (pseudonimów, postaci, narratorów, podmiotów lirycznych) była rzeczywistością z gruntu hipotetyczną, rekonstruowaną intelektualnie, z poznawczego dystansu, słowem, rzeczywistością jedynie możliwą teoretycznie. 
Wynikała stąd węzłowa dla etyki egzystencjalnej myśl Kierkegaarda. Przeczyła jakiejkolwiek próbie petryfikacji etyki. Negowała każdą - literacką, kaznodziejską, filozoficzną, pedagogiczną itd. - formę dydaktyzmu, pouczania i moralizowania. Otóż autor Postscriptum pisał:

Jeden człowiek nie może etycznie sądzić drugiego, albowiem jeden człowiek potrafi zrozumieć drugiego tylko jako możliwość. Natomiast wtedy, gdy ktoś zdradza chęć osądzenia kogoś innego, to świadczy to w istocie o jego niemocy, albowiem sądzi on wówczas jedynie samego siebie ${ }^{11}$.

Kierkegaard zakładał, że we wnętrzu jednostki jej własna rzeczywistość etyczna i własne, subiektywne myślenie - inaczej niż w zdystansowanej postawie i relacji poznawczej do świata zewnętrznego - zlewają się ze sobą, a jednostka (den Enkelte) jest zasadniczo istotą w pełni lub prawie $\mathrm{w}$ pełni przejrzystą jedynie w sobie i dla siebie samej. Była ona również $\mathrm{z}$ tego względu istotą socjalnie izolowaną i samotną, zgodnie $\mathrm{z}$ formułą, że człowiek pojedynczy jest samotny.

\section{TEOLOGICZNY I RELIGIJNY SENS KATEGORII MOŻLIWOŚCI}

Możliwość przybrała u Kierkegaarda znaczenie teologiczne i religijne, wynikające z niezwykle szerokiej i wielokontekstowej interpretacji znanej ewangelicznej formuły „dla Boga wszystko jest możliwe” (Mk 10, 25-27), którą zresztą omówię dalej bardziej szczegółowo. W tym miejscu należy podkreślić, że formuła ta uzasadniała w wywodach duńskiego pisarza nieskończoną jakościową różnicę i brak współmierności między istotą boską i ludzką. Bóg uosabiał bowiem, zgodnie z przytoczoną formułą ewangeliczną, niczym nieograniczoną pełnię możliwości, podczas gdy jednostka, która próbowałaby żyć tak, jak gdyby istniały wyłącznie możliwości i dla której wszystko - niczym dla samego Boga - wydawałoby się możliwe, skazywałaby się de facto na życie w iluzyjnym, pustym świecie fantazji i fikcji. Taka była, zdaniem duńskiego autora, egzystencjalna postawa estety, unikającego życiowych wyborów i związanej z nimi odpowiedzialności oraz delektującego się różnorodnością i zmiennością doświadczanych możliwości. Efektem takiej postawy, analizowanej w Albo-albo, była jednakże utrata

${ }^{11}$ Ibidem, s. 27. 
osobowości, pustka i nuda. „Nadczłowiecza” boskość estety okazywała się jedynie parodią wszechmocy Stwórcy.

Dlatego, teologicznie rzecz ujmując, realny, ziemski i doczesny człowiek stanowił według Kierkegaarda syntezę możliwości i konieczności. Istnienie konieczności i jej akceptacja miały tutaj - w przeciwieństwie do istoty boskiej - zastosowanie uniwersalne. Dawały o sobie znać zarówno w planie religijnym, jak i świeckim. Uzmysławiały bowiem u człowieka potrzebę i zdolność posłuchu (kraft at lyde) wobec przemożnej (nie do zwalczenia lub cofnięcia) siły konieczności oraz skłaniały do moralnego i praktycznego podporządkowania się jej.

Świadomość istnienia konieczności powodowała również w planie psychologicznym, moralnym i praktycznym akceptację własnej, ludzkiej ograniczoności. Człowiek religijny to znamię konieczności łączył w pierwszym rzędzie z treścią boskich przykazań oraz z nieprzekraczalnym wymogiem bezwzględnego posłuchu i stosowania się do nich, na przekór zachciankom wolnej woli oraz pokusom i kaprysom wolności. Tymczasem człowiek świecki istnienie konieczności wiązał z kolei z przemożnymi siłami przyrody, przymusem społecznym oraz mechanizmami historii. Wszystkie te trzy instancje były w mocy narzucać swoje prawa i warunki nie tylko jednostkom, lecz także całemu rodzajowi ludzkiemu.

Tymczasem alternatywna postawa, uznająca istnienie możliwości osadzonych w ludzkiej podmiotowej egzystencji, wolności i zdolności działania, leczyła z unicestwiającej beznadziei determinizmu i fatalizmu (SV, 2, s. 42). Uruchamiała trzeźwy i odpowiedzialny aktywizm respektujący lokalne i uniwersalne konieczności. Otwierała etyczną perspektywę przejścia od możliwości czynienia dobra do jego urzeczywistnienia za sprawą działania. Dostrzegła też bogactwo możliwości skumulowanych w istniejącej rzeczywistości, a tym samym możliwość jej pożądanej zmiany i transformacji, słowem - przejścia ab esse ad posse. Nie pozwala zatem stracić wiary w przyszłość.

Z kolei u ludzi usposobionych religijnie perspektywa możliwości - zgodnie z formułą „dla Boga wszystko jest możliwe” - nie pozwalała tracić nadziei zbawienia „mimo wszystko” - w obliczu przytłaczającego, rozpaczliwego brzemienia grzechu i dręczącego poczucia winy. Możliwość znaczyła tutaj pokonanie i przekroczenie niemożliwości. Dopuszczała możliwość zwycięstwa nad niemożliwością. Tworzyła więc rodzaj teologicznego pomostu 
między ziemską immanencją, napiętnowaną ponurym grzechem pierworodnym, a zbawczą transcendencją, obiecującą pośmiertnie wieczną błogość.

\section{LITERACKIE ASPEKTY I FUNKCJE MOŻLIWOŚCI}

Kategoria możliwości znalazła wszechstronne, oryginalne zastosowanie w pisarstwie Kierkegaarda. Oto jak ujmował rzecz filozof podpisany jako Johannes Climacus w Kończącym nienaukowym postscriptum, porównując estetyczny patos poetycki z patosem etycznym:

[...] rzeczywistość jest dla poety tylko bodźcem, który w istocie skłania go do tego, by opuścić rzeczywistość i szukać idealizacji w sferze możliwości. Właściwy dla niego patos jest patosem poetyckim, patosem w sferze możliwości z rzeczywistością funkcjonującą w charakterze pobudki; jeśli patos ten dotyczy nawet dziejów powszechnych, to jest to także tylko patos możliwości - patrząc zaś na to z kolei etycznie, jest to niedojrzałość, ponieważ dojrzałość etyczna polega na tym, by własną rzeczywistość etyczną ujmować jako nieskończenie ważniejszą niż odbiór całej choćby historii powszechnej. [...]

Najwyższym patosem w stosunku do możliwości jest słowo, najwyższym patosem w stosunku do rzeczywistości jest czyn, działanie. [...] Najwyższą wartością estetyczną są kreacja poetycka i możliwość, zaś etycznie występuje zależność odwrotna, albowiem pod względem etycznym dzieło poetyckie jest nieskończenie obojętne, podczas gdy własna egzystencja powinna być dla poety ważniejsza niż wszystko inne. Najwyższym patosem estetycznym dla poety byłoby zatem zniszczenie samego siebie, pełna demoralizacja po to, aby tylko stworzyć wybitne dzieło poetyckie (SV, 10, s. 83-85).

Przy preferowanej kategorii możliwości inspiracją dla Kierkegaarda była tu prawdopodobnie Poetyka Arystotelesa, uznająca wyższość poetyckiej idealizacji nad historyczną faktografią - duński autor dezawuował i eliminował w pisarstwie realistyczną lub naturalistyczną przedmiotową referencyjność, ujednoznacznienie słowa i wypowiedzi ${ }^{12}$.

Podobnie też wykluczał asertywność i demonstrowanie autorytetu autorskiego narzucającego odbiorcy własny, wyłączny punkt widzenia pisarza;

12 Zob. B.H. Kirmmse, Poetry, History - and Kierkegaard, „Kierkegaard Studies. Yearbook" 2010: Kierkegaard's Late Writings, ed. by H. Schulz, J. Stewart, K. Verstrynge, s. 49-68. 
posługiwał się w tym celu strategią pseudonimów uniemożliwiającą bezpośrednie identyfikowanie danej wypowiedzi z pisarzem. Uważał, że postawa autorytetu autorskiego oraz identyfikacja tego rodzaju eliminują jakikolwiek niezależny i samodzielny wybór interpretacji i znaczeń ze strony odbiorcy, a w konsekwencji sprowadzają do minimum lub zgoła likwidują jego indywidualną podmiotowość (subiektywność).

Taka strategia homoficzna - określmy to stanowisko Kierkegaarda literaturoznawczym terminem Bachtina, wywiedzionym zresztą zapewne z lektur duńskiego pisarza i myśliciela - sankcjonowałaby pasywność i podrzędność odbiorcy i sytuowałaby autora w boskiej, nierównorzędnej wobec odbiorcy pozycji nauczyciela i mentora, podczas gdy deklarowanym i realizowanym celem Kierkegaarda-pisarza był z jednej strony autodydaktyzm, z drugiej nieprzerwane sokratyczne i majeutyczne budzenie uśpionej podmiotowości odbiorcy oraz uczestniczenie w porodzie prawdy ukrytej w głębinach jego psychiki, zagłuszanej, tłumionej i niwelowanej z kolei przez współczesne media i opinię publiczną. Służyły tym celom takie literackie wynalazki Kierkegaarda, jak pseudonimy i komunikacja pośrednia.

Budując opozycję literatury jako domeny idealnych możliwości oraz rzeczywistości jako domeny spełnionych wydarzeń, stanów rzeczy i stosunków, Kierkegaard uwalniał literaturę od presji przedstawiania (odmalowywania) rzeczywistości w jej różnych postaciach, a w konsekwencji od programowych postulatów mimetyzmu, weryzmu, autentyzmu, realizmu czy naturalizmu. Na płaszczyźnie estetyki i poetyki stanowisko to równało się, z jednej strony, kategorycznej odmowie referencyjnych, naocznych lub pojęciowych przedstawień, wyprowadzających literaturę poza obręb literatury, motywujących ją zjawiskami wobec niej zewnętrznymi. Z drugiej strony - prowadziło ono także do uniejednoznacznienia literatury we wszystkich aspektach: zarówno w obrębie tego, o czym mowa, jak i w samym literackim mówieniu.

\section{MOŻLIWOŚĆ I JEJ FILOZOFICZNE UWIKŁANIA}

W pośrednim i bezpośrednim związku z kategorią możliwości, która tylko w niektórych sytuacjach występowała w izolacji i samodzielnie, funkcjonowały u Kierkegaarda skorelowane $\mathrm{z}$ nią inne zjawiska, pojęcia i kategorie. Dotyczyły one podmiotu, egzystencji i otaczającej rzeczywistości, pojętej dwojako: jako świecka, materialna i historyczna rzeczywistość immanentna oraz jako nadbudowana nad nią, rządzona innymi racjami i wymogami 
rzeczywistość transcendentna, nadprzyrodzona. Duński myśliciel wyróżniał w tej pierwszej w szczególności ludzkie postawy i poglądy na życie (livs-anskuelser) oraz realia światowe (verdenslige) obejmujące pojedyncze jednostki, społeczeństwo, rozmaite formacje zbiorowe, relacje międzyludzkie, instytucje, rodzaje praktyk itd.

Jego uwagę skupiały na sobie przede wszystkim ludzkie „stadia na drodze życia”, które różnicowały odmienne sfery wartości, postawy i sposoby egzystowania. Wyodrębniał zatem w tej dziedzinie trzy główne stadia: estetyczne, estetyczne i religijne, a także kilka stadiów pośrednich, usytuowanych niejako „pomiędzy” tymi głównymi i umożliwiających przejścia między nimi. Stadium estetyczne znamionowało na przykład postawy dające upust naturalnym, zmysłowym, cielesnym i mentalnym predyspozycjom i skłonnościom ludzkim, postawy osadzone w immanentnej rzeczywistości światowej i społecznej, wychylone ku temu, by rozkoszować się życiem (at nyde livet) i czerpać z niego maksimum satysfakcji, bez oglądania się na innych i na wyższe wartości wymagające samoograniczenia i dyscypliny. Tą najwyższą wartością była bowiem w estetycznym (konsumpcyjnym) sposobie życia wspomniana osobnicza rozkosz ${ }^{13}$. Sfera możliwości egzystencjalnych ulegała tu oderwaniu od rzeczywistości, konieczności, wyborów i obowiązków. Stawała się grą i rodzajem estetycznego urozmaicenia. W egzystencji tego typu zawiązywała się w efekcie konfliktowa relacja między estetycznie - inaczej: zabawowo, w sposób rozrywkowy - traktowaną kategorią możliwości a etyką i wiarą religijną, zwróconym ku doświadczaniu lub realizacji innych, alternatywnych lub wręcz wykluczających się wartości. Ich przykładem były motywowane etycznie wybory, obowiązki i działania albo motywowane $z$ kolei religijnie czyny ofiarne, wyrzeczenia i cierpienie.

Kierkegaard przyjmował jednakże, że egzystencjalne wartości etyczne i religijne realizują się w prawdzie w realnym świecie i w cielesno-zmysłowej egzystencji jednostki, ale zwracają się zarazem przeciwko bezpośrednim, naturalnym, zmysłowym skłonnościom człowieka i panującym stosunkom światowym. Tylko w ten sposób egzystencja jednostki uzyskiwała wiarygodny, autentyczny charakter, podczas gdy luźna, konsumpcyjna egzystencja estetyczna - zaprezentowana w swych rozmaitych odmianach w pierwszym

13 G.J. Stack, Kierkegaard's Concept of Possibility, „Journal of Thought” 1970, Vol. 5, No. 2, s. 80-92. 
tomie Albo-albo i kilku następnych pismach pseudonimowych - delektująca się różnorodnymi możliwościami, ceniąca ich zmienność i barwność - tak puste przecież w oderwaniu od praktyki i realizacji - stanowiła de facto wyraz ucieczki od życia i formę alienacji. Przynosiła ona w efekcie, zdaniem Kierkegaarda, przygnębienie, melancholię i rozpacz. Stanowiła jaskrawy symptom cywilizacyjnej, duchowej „choroby na śmierć”.

Alternatywą dla wspomnianego estetyzmu - stanowiącego dla Kierkegaarda znamię „nowych czasów” i postępującej świeckiej kultury oświeceniowej, romantycznej i modernistycznej - stawał się swoisty etyczny i religijny ascetyzm i rygoryzm, ale nie na zasadzie odwrócenia się od świata lub pustelniczej czy klasztornej ucieczki od niego, lecz pragnienia podjęcia aktywnej i nasyconej pasją walki z jego sensualnymi i intelektualnymi „aberracjami”. W planie filozoficznym postawę tę wyrażała na przykład krytyka Kantowskiej rzeczywistości $A n$-sich, metafizycznego pojęcia bytu (duń. veren) jako znieruchomienia i trwania, Heglowskiej zasady jedności myślenia i bytu, tożsamości tego, co wewnętrzne i co zewnętrzne itd.

Torując drogę otwartym, dynamicznym rozwiązaniom antropologiczno-egzystencjalnym i promując „bycie subiektywnym” i „bycie nieskończenie, namiętnie zaabsorbowanym własną, subiektywną egzystencją”, Kierkegaard dokonywał więc rozbiórki abstrakcyjnych, spekulatywnych dyskursów filozoficznych epoki. Obiektem tej rozbiórki stawały się takie osiowe dla nich terminy i pojęcia, jak voren ('byt'), rene voren ('czysty byt'), at vore ('bycie'), mediation lub mediere ('zapośredniczenie'). Duński myśliciel przeciwstawiał im własne, nacechowane pozytywnie pojęcia implikujące lub konotujące pierwiastek ruchu i dziania się: wieloznaczne tilblivelse ('stawanie się,' 'powstanie', 'stworzenie', 'przyjście'), at vaere til ('istnienie'), at existere ('egzystowanie'), virkelighed ('rzeczywistość'), vorden ('stawanie się'), at blive til ('powstanie', 'zaistnienie'), at vaere $i$ vorden ('bycie w trakcie stawania się'), at saette $i$ vorden ('wprawianie w stawanie się'), tilvorelse ('egzystencja', 'życie'), tilvoer ('istnienie', 'bycie'), overgang ('przejście'), spring ('skok'), bevogelse ('ruch'), modsigelse ('sprzeczność'), stroeben ('dążenie'), tid ('czas'), rum ('przestrzeń') itp. Analogiczną funkcję pełniła w jego rozważaniach dodatnia, interpretowana egzystencjalnie, antropologicznie, teologicznie i literacko kategoria możliwości i „możliwości możliwości”, pozwalająca przekraczać „próg skończoności” i „rzeczywistości immanentnej (ziemskiej, 
naturalnej)" oraz kierować wzrok ku wyższej, nieskończonej rzeczywistości transcendentnej.

Wszystkie wspomniane terminy występowały wprost lub pośrednio w filozoficznym dyskursie Johannes Climacusa w Zamykajacym nienaukowym postscriptum oraz w innych filozofujących pismach Kierkegaarda, tak pseudonimowych, jak autorskich. Cechowała je zwykle zamierzona wieloznaczność, stanowiąca sama w sobie akt polemiki Kierkegaarda zarówno z ustatyczniającymi i unieruchamiającymi określeniami właściwymi metafizyce i popularnemu w epoce dyskursowi spekulatywnemu, jak i z dyskursami nauki i wiedzy naukowej, zwróconymi ku naturze i rzeczywistości światowej, ignorującymi subiektywność, egzystencję i stawanie się osobowości. Wewnętrzny ruch, niepokój, zwroty, przesunięcia i operacje metaforyczne odzwierciedlały we wspomnianych pismach Kierkegaarda jego krytyczny stosunek do samochwalczo i deklaratywnie „obiektywnych” dyskursów epoki, charakteryzujących się - z racji omijania problematyki subiektywności, egzystencji oraz „możliwości zaistnienia tego, co w kategoriach rozumu i sensualnego doświadczenia niemożliwe" - jednostronnością, cząstkowością i deficytem prawdy.

Pisma Kierkegaarda świadczyły, że świadomie, obficie i niemal na każdym kroku posługiwał się językiem i pojęciami filozoficznej analizy rzeczywistości głównie (chociaż nie wyłącznie) po to, aby poddać ją krytycznej, polemicznej, satyrycznej, ironicznej lub parodiującej i ośmieszającej rozbiórce. Urzeczawiał i kompromitował w ten sposób „obiektywny” język „niezawodnej” wiedzy o pozapodmiotowej rzeczywistości. Kojarzył z nim konotacje negatywne za sprawą krytycznego wykładu nacechowanego emocją, obrazową ekspresją, ironią, satyrą, sarkazmem itp.

Rozbiórka obiektywnej wiedzy o pozapodmiotowej rzeczywistości przejawiała się tutaj w jej obezwładnieniu i w ubezwłasnowolnieniu, w ekspresywnym i intelektualnym zapanowaniu nad nią oraz podporządkowaniu jej zasadom własnej, egzystencjalnej koncepcji światopoglądowej i filozoficznej. Postępując zgodnie z głoszoną przez siebie teorią nauki i wiedzy, które prezentowały według niego jedynie możliwość prawdy, a nie obligującą, bezwzględną i ostateczną prawdę faktyczną lub teoretyczną, Kierkegaard podważał autorytet oraz roszczenia poznawcze i filozoficzne współczesnej sobie nauki i wiedzy naukowej. Kategoria możliwości ukazywała w tej dziedzinie ukryty w niej potencjał polemiczny i destrukcyjny. 
Aby zburzyć i skompromitować „obiektywną” i „abstrakcyjną” wiedzę pozapodmiotową, duński myśliciel starał się przyswoić sobie jej założenia i zasady, przeniknąć jej logikę, nabyć dyskursywnej biegłości w posługiwaniu się właściwymi dla niej pojęciami, terminami i kategoriami, ironicznie stylizować, imitować i przedrzeźniać charakterystyczne dla niej dyskursy. Świecka wiedza naukowa oraz filozofia pojęta jako prawda absolutna stanowiły bowiem $\mathrm{w}$ jego oczach śmiertelne, modernistyczne zagrożenie dla wiary i człowieka wierzącego. Zwalczając je, Kierkegaard używał w tym względzie tak zwanej komunikacji pośredniej i poetyki pseudonimowej oraz odwoływał się do decyzyjnej podmiotowości odbioru, zdolnego uchylić autorytatywny i asertywny charakter wypowiedzi skierowanej do czytelnika. Stawiał mianowicie czytelnika wobec konieczności podjęcia samodzielnej decyzji „komu wierzyć”: temu czy innemu pseudonimowi, autorowi, potocznej opinii, autorytetom itd. Żądał od czytelnika wiążącego, egzystencjalnego rozstrzygnięcia, czy ma do czynienia $z$ autorską powagą i serio, czy przeciwnie $-\mathrm{z}$ kpiną, ironią, parodią; słowem $-\mathrm{z}$ dystansem i negacją.

Warto dodać, że niektóre pisma Kierkegaarda - jak Okruchy filozoficzne lub Stadia na drodze życia - podejmowały węższe i bardziej specjalistyczne dziedziny czy zakresy wspomnianych zagadnień filozoficznych. Przykładem mogą być bogate zasoby terminów i pojęć stosujących się do problemów historii w pierwszym z wymienionych pism (tid, tilblivelse, forandring, samtidighed, naervaerende, forbigangne, tilkommende, aarsag i in.). Wskazywały one, że Kierkegaard nie ograniczał swych zainteresowań - jak czynił to w monumentalnym Nienaukowym kończacym postscriptum - do krytyki problematyki ogólnej (metafizycznej, filozoficznej, teologicznej), lecz kierował je także ku kwestiom szczegółowym, w tym wypadku ku popularnej w jego epoce problematyce filozofii historii. I tu również omawiana kategoria możliwości znajdowała szerokie zastosowanie

Kluczowa dla niniejszych rozważań wydaje się w szczególności relacja między takimi terminami i pojęciami rozważanymi przez Kierkegaarda, jak veren, vorden, tilblivelse, mulighed ('byt', 'stawanie się, 'powstanie', 'możliwość). Określenia te pozostawały u niego w mniej czy bardziej sprecyzowanej opozycji do tradycji filozoficznej i do ich ujęć przez klasycznych autorów, jak też we wzajemnej opozycji do siebie. Dotyczyło to zwłaszcza opozycji bytu (vaeren) - jako pustej, filozoficznej lub teologicznej abstrakcji, wyrazu ogólności i istnienia unieruchomionego (statycznego) - oraz 
możliwości (mulighed), stawania się (vorden) czy powstania, pojawienia się, objawienia się czegoś (tilblivelse). Preferencje Kierkegaarda wyraźnie kierowały się ku stawaniu się, obejmującemu zarówno powstanie i dzianie się bytu, jak i ludzką egzystencję, rozdartą między skończoność i nieskończoność, czasowe i wieczne, zmysłowe i duchowe, ale jednocześnie stale pobudzaną i wprawianą w ruch przez te konfliktowe i niemożliwe do zapośredniczenia sprzeczności.

Trzeba jednak podkreślić elastyczność i względny charakter podobnych opozycji. Otóż kategoria możliwości przybierała z punktu widzenia samego estety zabarwienie w zasadzie pozytywne - pozwalała bowiem beztrosko rozkoszować się życiem i uchylać się od odpowiedzialności za nie - podczas gdy z punktu widzenia etyka i człowieka religijnego uzyskiwała znaczenie negatywne i polemiczne, gdyż uosabiała dla nich jedynie zmienność pozorną oraz prowadziła w ich ocenie do egzystencjalnego bezruchu, stagnacji i rozpaczy. W planie epistemologicznym kategoria ta uzyskiwała znaczenie równie ambiwalentne, gdyż - z jednej strony - demaskowała i denuncjowała aspirujące do obiektywizmu, prawdy i pewności poznanie naukowe jako możliwe, a więc skażone pierwiastkiem subiektywnym i nieostateczne. Pozytywne w niej było zatem to, że oczyszczała poznanie od nieuprawnionych roszczeń. $Z$ drugiej zaś strony - jej negatywizm wyrażał się w podrywaniu do zaufania nauce i wiedzy. Pozytywne konotacje możliwości przeważały w zastosowaniu do stawania się bytu i do podstaw egzystencji. Gdyby bowiem możliwość zanikła, ruch stawania się i powstawanie nowych zjawisk byłyby z gruntu niemożliwe. Historia utraciłaby więc nadzieję na zmiany istniejących stanów rzeczy i tworzenia nowych, zaś egzystencja pozbyłaby się wiary w możliwość niemożliwego - tego, co przeczy rozumowi i rzeczywistości. Gdyby zaprzeczyć z kolei ewangelicznemu (teologicznemu) twierdzeniu, że „dla Boga wszystko jest możliwe”, to żaden bogacz nie byłby w stanie przecisnąć się przez ucho igielne przykazań wiary i doświadczyć zbawienia, a zatwardziałym grzesznikom byłaby odjęta wszelka możliwość łaski i wiecznej szczęśliwości po śmierci. 


\section{POZNANIE I DZIA PODMIOTU I WIARY}

Zatrzymajmy się nad epistemologicznymi oraz sprawczymi aspektami kategorii możliwości. Otóż Kierkegaard uznał, że pojęcie wiedzy o rzeczywistości obiektywnej, istniejącej na zewnątrz podmiotu jest wewnętrznie sprzeczne i niemożliwe do zaakceptowania. Zajęte przez niego stanowisko w następujący sposób referował Barry Stocker w tekście pod tytułem Kierkegaard's Epistemology:

Ponieważ wiedza należy do podmiotu, nie może ona według Kierkegaarda znajdować się całkowicie na zewnątrz jego subiektywności. Przedmiot tej wiedzy jest poznawany przez subiektywność, wiedza ta nie może więc być absolutnie obiektywna. Kierkegaard jest jednak antysolipsystą, gdyż uważa, iż podmiot może dysponować wiedzą, aczkolwiek nie jest ona absolutna. [...] Epistemologia Kierkegaarda jest więc subiektywistyczna w mocnym rozumieniu, ponieważ opiera się na podwójnej refleksji, w której wiedza refleksyjna odzwierciedla uprzednie przekonanie, że coś jest na rzeczy ${ }^{14}$.

Dobrze oddaje wysiłek precyzującego tę epistemologię Kierkegaarda wypowiedź z Postscriptum, z trzeciego rozdziału zatytułowanego Rzeczywista subiektywność, etyczny, subiektywny myśliciel. Określa ona relacje między jednostką, innymi jednostkami, otaczającym światem, wiedzą i etyką, a jednocześnie eksponuje poznawczy sens i filozoficzny status kategorii możliwości. Kierkegaard, ukryty pod pseudonimem Climacus Johannes, dowodzi w niej, że:

Każda wiedza o rzeczywistości jest możliwością; natomiast jedyną rzeczywistością, o której egzystujący dowiaduje się znacznie więcej, jest jego własna rzeczywistość, mianowicie to, że on istnieje; i ta właśnie rzeczywistość absorbuje go w sposób absolutny. Abstrakcja apeluje do niego o bezinteresowność, która warunkuje poznanie przedmiotowe; etyka apeluje natomiast o to, by pozostał on nieskończenie zainteresowany własnym egzystowaniem.

Jedyną rzeczywistością w pełni dostępną dla egzystującego jest jego własna rzeczywistość etyczna. Do każdej innej rzeczywistości ma on dostęp jedynie

${ }^{14} \mathrm{https} / /$ stockerb.wordpress.com/2007/12/17/kierkegaards-epistemology/ [data dostępu: 5.05.15]. 
za pośrednictwem prawdziwej wiedzy, która wszakże jest przeniesieniem i translacją [er oversaetten] w możliwość (SV, 10, s. 22).

Tylko znosząc rzeczywistość, abstrakcja jest w stanie przyswoić ją sobie, ale zniesienie rzeczywistości polega właśnie na zamianie jej w możliwość. Toteż wszystko, co abstrakcja orzeka abstrakcyjnie o rzeczywistości, orzeka ona w trybie możliwości (SV, 10, s. 21).

Założenia te kwestionowały w rezultacie możliwość bezpośredniego poznawczego dotarcia do jakiejkolwiek innej rzeczywistości niż własna rzeczywistość subiektywna podmiotu poznającego, aczkolwiek nie kwestionowały bynajmniej istnienia rzeczywistości znajdującej się poza zasięgiem tegoż podmiotu. Negowały natomiast możliwość zdobycia niezawodnej, bezspornie prawdziwej i pewnej wiedzy o jakiejkolwiek przedmiotowej rzeczywistości zewnętrznej. Rzeczywistość inna niż subiektywna pozostawała dla Kierkegaarda po prostu swego rodzaju Kantowską „rzeczą samą w sobie”, oferującą jedynie teoretyczną „możliwość” uzyskania o niej prawdziwej i niezawodnej wiedzy, ale bynajmniej nie definitywną, niepodważalną pewność uzyskanej wiedzy. Pewność i niezawodna prawdziwość wiedzy o przedmiotowej rzeczywistości były w istocie nieosiągalne, gdyż każda taka wiedza - właśnie jako wiedza - podlegała przedestylowaniu przez filtr subiektywności podmiotu. Uzyskiwała wówczas epistemologiczny status wiedzy możliwej, zawartej w przekonaniu, że być może jest (było) tak, a nie inaczej, ale i że wiedza ta może ulec modyfikacji, względnemu potwierdzeniu albo zgoła unieważnieniu pod wpływem kolejnych badań i nowych danych.

Podważając prawdziwość i pewność zdobywanej w ludzkim poznaniu wiedzy zmysłowej, historycznej i teoretycznej (spekulatywnej), Kierkegaard podkreślał zarazem, iż zawsze i bez wyjątku wiedza tego typu podlegała subiektywnemu (egzystencjalnemu) „zapośredniczeniu” oraz transformacji i transkrypcji we wspomnianą „możliwość”. Podlegała zatem wewnętrznej logice myślowej idealizacji. Toteż adekwatna, absolutnie pewna poznawcza reprezentacja jakiejkolwiek pozapodmiotowej rzeczywistości przedmiotowej była z tego względu niemożliwa i nieosiągalna. Heglowska zasada tożsamości myślenia i bytu była więc w odbiorze Kierkegaarda jedynie utopią, obowiązywały natomiast według niego niewspółmierne i nieprzekraczalne jakościowe różnice właściwe różnym sferom bytu - w tym wypadku idealizującej myśli i przedmiotowej rzeczywistości. 
Heglowską zasadę tożsamości myślenia i bytu zastępowało natomiast przekonanie Kierkegaarda o otwartości i strukturalnej niedomkniętości poznania oraz o względnej nieokreśloności i nierozstrzygalności wiedzy (o jej z konieczności subiektywnym i egzystencjalnym, relatywizującym zapośredniczeniu), przywodzące na myśl analogię ze współczesną nam zasadą nieoznaczoności Heisenberga. Rozstrzygała o tym niewzruszona maksyma, iż „,w stosunku do każdej innej rzeczywistości niż własna dane indywiduum może dysponować wiedzą tylko i wyłącznie za sprawą pomyślenia o niej”. Uchem igielnym wiedzy o rzeczywistości przedmiotowej zewnętrznej wobec podmiotu było tedy własne pomyślenie tej rzeczywistości, którego nie sposób było zastąpić pomyśleniem kogoś innego lub czymś innym niż pomyślenie. Tym samym żadne poznawcze, rzeczowe i przedmiotowe rozważanie i dociekanie nie przybliżało jednostki do otaczającego świata, istniejącego realnie, zewnętrznie i zmysłowo poza nią samą. Kierkegaard nobilitował $\mathrm{w}$ ten sposób, po pierwsze, wnętrze podmiotu i poznanie subiektywne, po drugie - czynił miejsce dla wiary, skoro wiedza zawierała pierwiastek strukturalnej niepewności.

Wnioski były jasne. Drzwi do pewnego, konkludującego i definitywnego poznania zewnętrznej, intersubiektywnej lub obiektywnej rzeczywistości istniejącej poza subiektywnie egzystującą jednostką były zatrzaśnięte, albowiem jednostkę od rzeczywistości tego typu dzieliła nieprzebyta, jakościowo różna sfera myśli, rządzona przez pojęcia, idealność i możliwość, nieprzenikalna bezpośrednio dla świata zewnętrznego, nieprzekładalna na różne od „myślącej myśli” kategorie bytowe: na rzeczy, zdarzenia, jakości zmysłowe czy interpersonalne stosunki. Dotyczyło to bez różnicy każdego pojedynczego człowieka występującego w stosunku do nas jako „ktoś inny”, „drugi” czy „obcy”, a także nas samych w odwróconej roli.

Kierkegaard negował w konsekwencji pełnienie przez wiedzę przejrzystej, jednoznacznej i wiarygodnej funkcji reprezentacyjnej i kognitywnej, a tym samym zdolność do ominięcia, zneutralizowania lub zignorowania relatywizującego filtru subiektywności, zastępującego pewność i faktyczność możliwością. Ponadto kwestionował subiektywną i egzystencjalną przydatność immanentnej wiedzy przedmiotowej, generującej „dystrakcję" i zapomnienie o człowieczeństwie, ludzkim powołaniu i transcendencji. 
Przyjmując tę platformę epistemologiczną, duński autor na długo przed Derridą dezawuował „iluzję obecności” zawartą w przekonaniu, że wiedza obiektywna jest lustrzanym odbiciem niezależnego od niej „bycia bytu”.

Kierkegaard wykazywał ponadto, iż funkcjonujące w jego epoce kategorie metafizyczne i ontologiczne - zarówno dawne, jak i współczesne - nie mają żadnego innego ugruntowania niż tylko w abstrahującej myśli i w języku, a zatem referencyjnie i przedmiotowo są puste niczym „miedź brzęcząca”. Informowały de facto nie o stawaniu się bytu i egzystencji, lecz głównie o alienacji myśli i języka oraz - w planie podmiotowym - o dystrakcji i autoalienacji tych, którzy kategorie te tworzyli, wprowadzali do obiegu, wierzyli w nie i posługiwali się nimi, a więc głównie filozofów i spekulatywnych teologów, a zapewne także teoretyków literatury. Wbrew zaprzeczeniom tych ostatnich, ich roszczenia do „rządu dusz” stanowiły de facto jedynie „odpady” zdegradowanej antropologii, abstrakcyjnej psychologii oraz sofistycznej hermeneutyki.

Wprowadzając szeroko rozumianą kategorię możliwości, Kierkegaard eksponował, jak wcześniej wskazywałem, również jej sprawcze (pragmatyczne) zastosowania. Otóż w Chorobie na śmierć Anti-Climacus (a więc sam filozof) uznał możliwość za kardynalną właściwość samej natury Boga: „[...] albowiem Bóg sprawia, że wszystko jest możliwe, lub to, że wszystko jest możliwe, oznacza Boga [thi Gud er det at alt er muligt, eller at alt er muligt, er Gud]" (SV, 15, s. 97).

Wspomniana uwaga Anti-Climacusa-Kierkegaarda o naturze Boga nawiązywała do znanych fragmentów Ewangelii Marka, Mateusza i Łukasza, w tym wypadku do bulwersujących słów Jezusa, iż „łatwiej jest wielbłądowi przejść przez ucho igielne niż bogaczowi wejść do królestwa Bożego". Na zdziwienie i pytanie uczniów: „Któż więc może się zbawić?” odpowiedź Jezusa, jak czytamy u Marka, brzmiała: „U ludzi to niemożliwe, ale nie u Boga; bo u Boga wszystko jest możliwe” (Mk, 10, 25-27).

O fascynacji Kierkegaarda tą sceną i wypowiedzią Jezusa świadczyły liczne nawiązania do niej w różnych pismach, a zwłaszcza występujące w formie lejtmotywu w Chorobie na śmierć słowa „dla Boga wszystko jest możliwe" (for Gud er Alt muligt). Myśl ta, zdaniem duńskiego pisarza, wyrażała zarazem prawdziwą naturę Boga - to mianowicie, że Bóg jest możliwością (że skupia w sobie nieograniczone możliwości) i że autentyczna wiara w Boga przenosi się w ten sposób również na wiarę w istnienie i sprawczą, 
kreacyjną funkcję (moc) możliwości. Bez wiary w to, że dla Boga wszystko jest możliwe i że człowiek określa się wobec możliwości istnienia-nieistnienia, zatraca się chrześcijańska religijność i znika sama wiara. Zastępują ją determinizm, fatalizm lub sensualizm. To żywotne znaczenie możliwości obrazował u Kierkegaarda następujący przykład:

W ten sposób, biorąc to na ludzki rozum, zbawienie [Frelse] jest rzeczą najbardziej niemożliwą ze wszystkiego, ale przecież dla Boga wszystko jest możliwe! Na tym polega też walka wiary [Troens Kamp], która walczy, by tak rzec, w sposób szalony o możliwość: albowiem możliwość jest tą jedyną, która otwiera drogę do zbawienia. Gdy ktoś mdleje, woła się o zwykłą wodę, o wodę kolońską, krople Hoffmanna; ale gdy ktoś rozpacza, zbawia tylko i wyłącznie to: pokaż mu możliwość, pokaż mu ją, albowiem jedynie możliwość go uleczy; gdy więc pojawi się możliwość, to pogrążony w rozpaczy znowu oddycha i znowu ożywa; ponieważ jest tak, że człowiek wyzuty z możliwości jest jak bez tchu. Od czasu do czasu wynalazczość ludzkiej fantazji jest w stanie zdobyć się na stworzenie możliwości, ale koniec końcem, gdy rzecz dotyczy wiary, to pomaga jedynie to, że dla Boga wszystko jest możliwe (SV, 15, s. 95-96).

To odzyskiwanie tchu Kierkegaard pojmował więc religijnie. Uważał, że osoba wierząca dysponuje niezawodną odtrutką przeciwko paraliżującej ją rozpaczy, mianowicie przekonaniem o istnieniu możliwości i o tym, że „dla Boga wszystko jest możliwe w każdym momencie”. Wiara rozwiązywała więc w rezultacie, zdaniem Kierkegaarda, sprzeczność między spodziewanym nieuchronnym potępieniem a możliwością zbawienia (SV, 15, s. 96). Dlatego kategoria możliwości warunkowała niejako samo istnienie wiary - w świecie determinizmu, fatalizmu i konieczności nie było bowiem dla niej miejsca.

Postawa tego typu, zauważmy, ulegała jaskrawej radykalizacji w stosunku do nadbudowanej nad sferą etycznej egzystencji religijnej zwróconej ku wierze w boski absolut; zwłaszcza sferą religijności specyficznie chrześcijańskiej, sygnowanej w Nienaukowym kończacym postscriptum jako „religijność B”. Religijność tego typu z góry odrzucała wszelkie racjonalne, rzeczowe i obiektywne wyjaśnienia dotyczące realnego (esencjalnego) istnienia absolutu jako zwodzące. Akceptowała natomiast wiarę jako paradoksalną, „obiektywną niepewność", wzmacnianą dodatkowo przez poczucie absurdu. Jednostka oddana „religijności B” zachowywała mimo wszystko mocną 
wiarę w boskość, a to za sprawą spotęgowanej do maksimum i całkowicie pochłaniającej ją namiętności wewnętrznej (lidenskab i inderlighed).

Na zakończenie warto przytoczyć słowa angielskiej teolożki Clare Carlisle, autorki trzech książek o Kierkegaardzie:

Kierkegaard reminds us that without possibility we are not fully human. The 'choices' we hear so much about - which product to buy, which career politician to vote for - should not be mistaken for true possibility. (On the other hand, resistance to spiritless philistines, certain university managers included, remains possible.) If God is 'that all things are possible', then the question of what it means to relate to God cannot be separated from the question of what kind of life we want to lead, and what kind of world we want to live in ${ }^{15}$.

\section{Bibliografia}

Clare Carlisle, Kierkegaard's Philosophy of Becoming: Movements and Positions, New York UP, New York 2005.

John W. Elrod, Being and Existence in Kierkegaard's Pseudonymous Works, Princeton Legacy Library, Princeton 2015 [1975].

Arne Grøn, Begrebet angst hos Søren Kierkegaard, Gyldendal, Kopenhaga 1994.

Arne Grøn, The Concept of Anxiety in Søren Kierkegaard, trans. J.B.L. Knox, Mercer University Press, Macon 2008.

15 „Kierkegaard przypomina nam, że bez możliwości nie jest się w pełni człowiekiem. »Wybory«, o których słyszymy tak wiele - który produkt kupić, na którego polityka głosować - nie powinny być mylone z prawdziwą możliwością. ( $Z$ drugiej strony, opór wobec bezdusznych Filistynów, w tym niektórych menedżerów uczelni, pozostaje możliwy). Jeśli dla Boga »wszystko jest możliwe«, to pytanie, co to znaczy odnosić się do Boga, nie może być oddzielone od pytania, jaki rodzaj życia chcemy wieść i w jakim świecie chcemy żyć" (tłum. M.C.), http://www.theguardian.com/ commentisfree/belief/2010/may/03/religion-philosophy-kierkegaard-possibilitygod [data dostępu: 5.05.15]. 
Sebastian Hüsch, Langeweile bei Heidegger und Kierkegaard. Zum Verhältnis philosophischer und literarischer Darstellung, Francke Verlag, Tübingen 2014. Søren Kierkegaard, Samlede Voerker, t. 1-20, Gyldendal, Kopenhaga 1962-1965. Bruce H. Kirmmse, Poetry, History - and Kierkegaard, „Kierkegaard Studies.

Yearbook" 2010: Kierkegaard's Late Writings, ed. by H. Schulz, J. Stewart, K. Verstrynge, s. 49-68.

George J. Stack, Kierkegaard'ss Concept of Possibility, „Journal of Thought” 1970, Vol. 5, No. 2, s. 80-92.

\section{Źródła internetowe}

Clare Carlise, Kierkegaard's world part 8: God and possibility, http:// www.theguardian.com/commentisfree/belief/2010/may/03/ religion-philosophy-kierkegaard-possibility-god.

Søren Kierkegaard, Den ethiske og den ethisk-religieuse Meddelelses Dialektik, Papirer VIII 2B 81.10, http://sks.dk/p364/txt.xml.

Barry Stocker, Kierkegaard's Epistemology, https://stockerb.wordpress. com/2007/12/17/kierkegaards-epistemology/

\section{Category of Possibility According to Søren Kierkegaard}

The article presents the category of possibility, inferred from Kierkegaard's works as one of primary for him. Contexts, responsible for both the typology of the concept, as well as an extension of its semantics and hermeneutical capabilities, situate at the same time the notion of possibility within the limits of modern and contemporary reflection on culture. The philosophical and theological existence of possibility as a basis for subjective recognition of the world of category culture, finally leads to the anthropological approach, in which the choice of will is being contrasted with externally interpreted histories and philosophies recognized in the spirit of historical Hegelianism.

Reflections on the 'opportunity' define and expand the concept itself, and in a way they also affect the individualistic figure of the philosopher-writer, whom turns out to be Kiekegaard. They bring out the specificities not only in the field of writing, but also polemics and dialogue. Having allowed us to understand the polemical nature of the notion of possibility, he shows 
culture - not only romantic and incoherent, but also contemporary, full of possibility, based on the choice of the path belonging to an entity participating in culture (believing, philosophizing, writing, operating, communicating with others).

Keywords: Kierkegaard, category of possibility, culture, entity 